\title{
AN UNEXPECTED CRISIS? \\ LOOKING AT PRICING EFFECTIVENESS OF HETEROGENEOUS BANKS
}

\author{
Valerio Vacca*
}

This version: October 2015

\begin{abstract}
Credit quality of loans to Italian firms dramatically worsened during the cyclical downturn of 2008-09, compared with the previous period of growth (2006-07). This paper shows that, if credit quality transition matrices (i.e. the change in the actual firms' riskiness, gauged ex post) are mapped to interest rates (i.e. the conditions applied ex ante to the credit), banks appear to have been able at calibrating required risk premiums to actual firms' idiosyncratic risk, both during expansion and recession. However, the uncertainty generated by the crisis emphasized the unexpected component of credit worsening, thus making evident flaws in pricing effectiveness. Moreover, banks' organizational features did matter in driving the pricing effectiveness: the main finding is that larger banking groups were more affected than smaller ones by the sudden deterioration of credit quality, which was poorly reflected in their risk pricing on the eve of the crisis. The bank-size effect can be tackled through an efficient use of hard or soft information: both the banks using quantitative credit rating models and highly decentralized banks showed an above-average ability in calibrating rates to upcoming risk, suggesting that a clear-cut adoption of a consistent lending technique outperforms more ambiguous strategies; banks with a strong relationship with borrowers smoothed the risk-price curve in normal times.
\end{abstract}

JEL classification: G01; G21; E43; E32

Keywords: banking; crisis; credit migration; credit risk pricing; heterogeneous banks

This is the author manuscript accepted for publication and has undergone full peer review but has not been through the copyediting, typesetting, pagination and proofreading process, which may lead to differences between this version and the Version of Record. Please cite this article as doi:10.1111/ecno.12077

\footnotetext{
* Bank of Italy, Financial stability directorate, valerio.vacca@bancaditalia.it.
} 


\title{
AN UNEXPECTED CRISIS?
}

\section{LOOKING AT PRICING EFFECTIVENESS OF HETEROGENEOUS BANKS}

\section{Introduction ${ }^{1}$}

\author{
Valerio Vacca*
}

This paper addresses the question of which banks were more affected by the sudden deterioration of credit quality at the peak of a financial crisis (2008-2009), as reflected in their ability to correctly price risk.

In order to answer this question, I compute the matrix of transitions across credit quality status for bank loans to Italian firms with reference to two distinct periods, before the crisis (2006-07) and a 'crisis' period (2008-09), and therefore use the inception of the crisis in 2008-09 as a natural experiment to gauge pricing effectiveness.

The focus of the paper is on the correspondence between the actual transitions in credit quality and the rates charged by banks to firms: risk pricing models state that interest rates should incorporate a risk premium, or spread, based upon the transition matrix estimated ex ante by the price setter. A weak correspondence signals that the actual riskiness of debtors has been assessed ex ante with poor accuracy. We can therefore detect for which banks credit deterioration had a larger unexpected component by looking at modifications in the link between interest rates and transitions in a untroubled period and in a period where, just after the price-setting, an unprecedented crisis occurred.

Two strands of literature are relevant to the present analysis. First, the effects of a crisis on rating migration patterns matter, as obligors' transitions between ratings are a key building block of credit risk models. A transition matrix characterizes the frequency or probability with which debtors within a portfolio shift across different credit qualities over a time horizon. It has been shown that the current regime of the economy or cross-section factors, such as the size, industry or location of the obligors, can affect these probabilities (Altman, 1998; Nickell et al., 2000; Bangia et al., 2002; Lando and Skodeberg, 2002). In particular, the impact of the business cycle suggests hypothesizing time non-homogeneity, therefore distinguishing between "expansion matrices" and "recession matrices". The correct estimation of these conditional matrices can modify the assessment of the amount of capital that financial institutions should post against their credit risk (Jafry and Schuermann, 2004). Allowing for conditional migration frequencies leads to a measure of the increase in uncertainty driven by an upsurge in unexpected losses for banks during a recession (Bangia et al., 2002). Estimates of the Value at Risk (VaR) of a credit portfolio can change in a non-trivial way ( 25 to 30 per cent) if the matrix is computed under time non-homogeneity. Kashyap and Stein (2004) show that capital requirements relating to a portfolio of credits can change following the cycle, and the size of this change depends on the method used to assess credit risk. Some credit risk assessment models explicitly assume that both transition probabilities and their correlations evolve over time (Nickell et al., 2000).

Bank of Italy, Financial stability directorate.

The views expressed in this article are those of the author and do not necessarily reflect those of the Bank of Italy. The author would like to thank for insightful comments Giorgio Albareto, Paolo Angelini, Paola Brighi, Marcello Bofondi, Luisa Carpinelli, Luci Ellis, Giovanni Ferri, Paolo Mistrulli, Richard Rosen, Nikola Tarashev, anonymous referees and participants at seminars held at the Bank of Italy (December 2010 and October 2011), at the University of Bari (May 2011), at the Reserve Bank of Australia, at the 24 ${ }^{\text {th }}$ Australasian Banking and Finance Conference (December 2011) and at the University of Modena and Reggio Emilia (March 2013). The usual disclaimer applies. 
The importance of a correct estimation of credit migration matrices also stems from the fact that banks' interest rates should be consistent with the estimated transitions of debtors, according to risk pricing models (Jarrow et al., 1997). This leads us to the second strand of literature, dealing with a specific microeconomic research topic which is at the core of this paper. It addresses the characteristics of the banks for which the link between ex ante rates and actual ex post debtors' riskiness has blurred to a greater extent owing to the crisis. This issue will be investigated having regard to two dimensions: bank size and the use of different types of information (hard and soft).

A look into the "black box" of bank size is needed to disentangle the specific contribution of other factors to price effectiveness. First, the effects of the adoption of rating systems on the cost of credit are ambiguous (Berger et al., 2002). The use of quantitative methods could allow banks to extend credit availability to risky businesses (marginal borrowers). The overall portfolio riskiness would not necessarily rise, however, if the idiosyncratic risk of single debtors is identified with greater accuracy. Nor is a clear-cut hypothesis possible with respect to average rates. Rates could become unable to account for ex post losses, e.g. if the bank uses ratings mainly for granting credit rather than for pricing it. In general, strong reliance on hard information, which is typically lagged (e.g. for balance-sheet data), and low reliance on soft information might jeopardize timely identification of credit cycle changes (Berger et al., 2005).

Against this background, organizational arrangements could provide incentives to the bank structure to collect relevant information. In particular, broader delegation to loan officers would make them more willing to gather and process non-transmittable soft information, which in turn might influence the effectiveness of credit pricing (Stein, 2002).

Finally, the intensity of bank-borrower relationships also matters in that it allows information accumulation and hence more accurate pricing. At the same time, stronger relationships also allow room for strategic pricing on the part of the bank: a bank relying on a strong and long-lasting relationship might find it convenient to smooth interest rates with respect to the (change in the) borrower's riskiness (Machauer and Weber, 1998; Petersen and Rajan, 1995). This could lead the main bank of a firm to display a relatively weak correspondence between rates and riskiness, especially during turmoil.

\section{Transition matrices of bank loans to firms and loan pricing}

The crisis which erupted after the Lehman collapse in 2008 resulted in a deterioration of credit quality for Italian banks which was not homogeneous across banking groups of different dimensions (Table 1).

Firm-level data in the Italian Credit Register database (Centrale dei Rischi, CR) can be used to fill a matrix of the frequencies at which bank loans shift through different states of impairment. The sample covers all the bank-firm relationships in the database, about 3 million observations. The frequencies are based on conditional transition matrices, i.e. referring to two biennial periods, 2006-07 and 2008-09 (Bangia et al., 2002). The method adopted implements a cohort approach, which is common in matrix computation (see Appendix A) ${ }^{2}$.

\footnotetext{
Lando and Skodeberg (2002). The cohort approach takes into account the situation of debtors at the start and the end of the period, disregarding transitions to other states during the period; moreover, statistical issues such as (right) censoring and (left) truncation are overlooked. This leads to a misalignment in transition estimates compared with sounder statistical methods, based on survival analysis. However, misalignment between different methods does not seem to be systematic, since within the same portfolio overand under-estimations can be found simultaneously for different classes. Matrix frequencies should in principle be monotonically decreasing moving away from the diagonal. Violations of monotonicity are often found, however, and might depend on the effect of infra-period transitions within the relevant horizon, i.e. over a shorter period than the reference horizon for the estimation of the final transition (Bangia et al., 2002).
} 
Table 1

\begin{tabular}{|c|c|c|c|c|c|}
\hline \multicolumn{6}{|c|}{$\begin{array}{l}\text { Italian banking groups: credit quality (1) } \\
\text { (shares of total credit to customers; per cent; } 2005-2009)\end{array}$} \\
\hline & 2005 & 2006 & 2007 & 2008 & 2009 \\
\hline & \multicolumn{5}{|c|}{ total banking groups (2) } \\
\hline Fully regular (a) & 93.8 & 94.9 & 95.4 & 93.5 & 90.9 \\
\hline Impaired (b) & 6.2 & 5.1 & 4.6 & 6.5 & 9.1 \\
\hline - past-due and overdraft & 0.7 & 0.4 & 0.4 & 0.5 & 0.8 \\
\hline - restructured & 0.2 & 0.3 & 0.1 & 0.2 & 0.6 \\
\hline - sub-standard & 1.9 & 1.1 & 1.1 & 2.0 & 3.0 \\
\hline - non-performing & 3.4 & 3.2 & 3.0 & 3.8 & 4.7 \\
\hline Total credit to customers $(a+b)$ & 100 & 100 & 100 & 100 & 100 \\
\hline \multicolumn{6}{|c|}{ of which: major banking groups (3) } \\
\hline Fully regular (a) & 93.5 & 94.9 & 95.2 & 93.2 & 90.1 \\
\hline Impaired (b) & 6.5 & 5.1 & 4.8 & 6.8 & 9.9 \\
\hline - past-due and overdraft & 0.7 & 0.4 & 0.3 & 0.5 & 0.7 \\
\hline - restructured & 0.1 & 0.4 & 0.2 & 0.2 & 0.7 \\
\hline - sub-standard & 2.2 & 1.1 & 1.1 & 2.1 & 3.3 \\
\hline - non-performing & 3.5 & 3.3 & 3.2 & 4.1 & 5.2 \\
\hline Total credit to customers $(a+b)$ & 100 & 100 & 100 & 100 & 100 \\
\hline
\end{tabular}

Source: Bank of Italy, Annual report, various years.

(1) Data retrieved from supervisory statistical reports. They are not perfectly comparable with Credit Register (CR) data reported in other tables. - (2) Includes Italian groups which are subsidiaries of foreign banks. - (3) Top five groups for total assets at the end of the reference year.

Table 2 presents transition matrices for bank loans to Italian firms. The distinction between expansion and recession matrices surfaces unambiguously. The bold figures in the 2008-09 matrix highlight entries which are statistically different from corresponding entries in the 2006-07 matrix (at the 1 per cent level). While frequencies in these matrices refer to the number of bank-firm relationships, matrices referring to the amount of bank credit exhibit very similar patterns (Table B.1 in the statistical appendix) ${ }^{3}$.

A main departure of credit amount-based matrices from headcount-based matrices relates to transitions from/to overdraft. This is due to the relative diffusion of minor overdraft situations and to the stricter definition of overdraft loans used in amount-based matrices. See Appendix A. 
Table 2

\begin{tabular}{|c|c|c|c|c|c|c|c|c|}
\hline \multicolumn{9}{|c|}{$\begin{array}{l}\text { Transition matrix between situations of impairment for loans to Italian firms (1) } \\
\text { (period } 31 \text { December } 2007-2009 \text { and } 2005-2007 \text {; percentage frequencies) }\end{array}$} \\
\hline \multirow{2}{*}{$\begin{array}{c}\text { State of the loan } \\
\text { at the initial date } \\
\text { of the reference } \\
\text { period }\end{array}$} & \multicolumn{8}{|c|}{ State of the loan at the final date of the reference period } \\
\hline & $\begin{array}{l}\text { Fully } \\
\text { regular }\end{array}$ & Overdraft & $\begin{array}{l}\text { Past-due } \\
<180 \text { dd }\end{array}$ & $\begin{array}{l}\text { Past-due } \\
>180 \text { dd }\end{array}$ & $\begin{array}{c}\text { Sub- } \\
\text { standard }\end{array}$ & $\begin{array}{l}\text { Non- } \\
\text { performin } \\
\mathrm{g}\end{array}$ & Loss & $\begin{array}{l}\text { N. loans } \\
(000)\end{array}$ \\
\hline & \multicolumn{8}{|c|}{ Panel a: "Recession” matrix (31 December 2007 to 31 December 2009) } \\
\hline Fully regular & 79.5 & 14.2 & 1.4 & 1.2 & 2.1 & 1.4 & 0.2 & 962.4 \\
\hline Overdraft & 43.1 & 35.3 & 3.4 & 3.3 & 8.0 & 6.0 & 0.9 & 267.4 \\
\hline Past-due $<180 \mathrm{dd}$ & 32.7 & 25.0 & 5.8 & 6.8 & 16.0 & 12.4 & 1.4 & 20.5 \\
\hline Past-due $>180 \mathrm{dd}$ & 30.1 & 19.7 & 4.2 & 10.9 & 19.5 & 14.2 & 1.3 & 19.6 \\
\hline Sub-standard & 7.4 & 6.5 & 1.2 & 1.6 & 41.3 & 37.5 & 4.4 & 24.6 \\
\hline Non-performing & 0.1 & & & & 0.1 & 94.7 & 5.1 & 256.0 \\
\hline \multirow[t]{2}{*}{ Loss } & & & & & & 10.4 & 89.6 & 82.1 \\
\hline & \multicolumn{8}{|c|}{ Panel b: “Expansion" matrix (31 December 2005 to 31 December 2007) } \\
\hline Fully regular & 81.1 & 15.1 & 1.1 & 1.0 & 0.8 & 0.8 & 0.1 & 847.4 \\
\hline Overdraft & 47.0 & 38.5 & 2.9 & 2.9 & 3.8 & 4.0 & 0.8 & 249.6 \\
\hline Past-due $<180 \mathrm{dd}$ & 35.5 & 31.5 & 5.6 & 7.7 & 8.7 & 9.3 & 1.6 & 20.8 \\
\hline Past-due $>180$ dd & 30.6 & 25.2 & 4.7 & 12.3 & 12.4 & 12.6 & 2.2 & 24.9 \\
\hline Sub-standard & 8.1 & 7.9 & 1.2 & 1.7 & 31.6 & 41.0 & 8.4 & 22.6 \\
\hline Non-performing & & & & & & 88.1 & 11.8 & 271.9 \\
\hline Loss & & & & & & 1.0 & 99.0 & 74.7 \\
\hline
\end{tabular}

Source: Central Credit Register. See Appendix A.

(1) Entries in the matrix represent the percentage frequencies at which bank-firm relationships, recorded in the state shown in the first column at the start of the reference period, moved towards the situation shown in the subsequent columns at the end of the following 24 months. Frequencies are reported as a percentage of the number of the bank-firm relationships in the sample belonging to the relevant initial state; they sum up to 1 by row. Values below 0.1 are not reported. Entries in bold for the 2007-09 matrix are statistically different from the corresponding entry in the 2005-07 matrix (at the 1 per cent confidence level). To perform these tests, I calculate t-statistics equal to the difference between corresponding entries in the first sample (2007 to 2009) and the second sample (2005 to 2007) transition probabilities divided by standard errors for the first sample estimate. The calculation is therefore conditional on the first sample probabilities. Standard errors are calculated under the simplifying assumption that rating transitions are temporally and cross-sectionally independent (Nickell et al., 2000).

Matrices can be compared through summary indicators (see Appendix A). A mobility index documents the speed of changes in credit quality, while a net deterioration index shows how much of this mobility is due to credit worsening. Figure 1, panel a, shows that credit quality mobility increased by about 12 percentage points between 2006-07 and 2008-09; this figure provides a quantitative estimate of the increase in uncertainty facing the banking business following the onset of the crisis. At the same time, the net deterioration index worsened from -6.0 to -7.4 per cent.

It is possible to quantify changes in matrices through distance metrics. Figure 1, panel b, displays distance metrics between recession and expansion matrices, ranging from 2.5 to 6 , depending on the specific segments of obligors. Transitions are more affected by business cycles for small firms, which therefore, according to this evidence, seem to have been hit harder by the downturn (Hancock and Wilcox, 1998). The matrices are also quite different across country areas, with major changes for companies in the Centre and South and for banks featuring different 
characteristics (Figure B.1) .

Figure 1

\section{Mobility, deterioration and the distance between expansion and recession matrices} (indicator values)

a: Mobility and deterioration in credit quality (1)

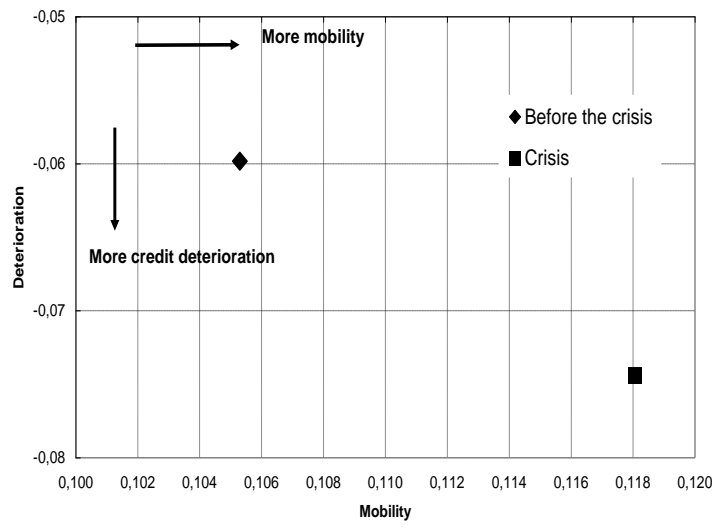

b: Distance: "expansion" Vs "recession transition matrices" (2)

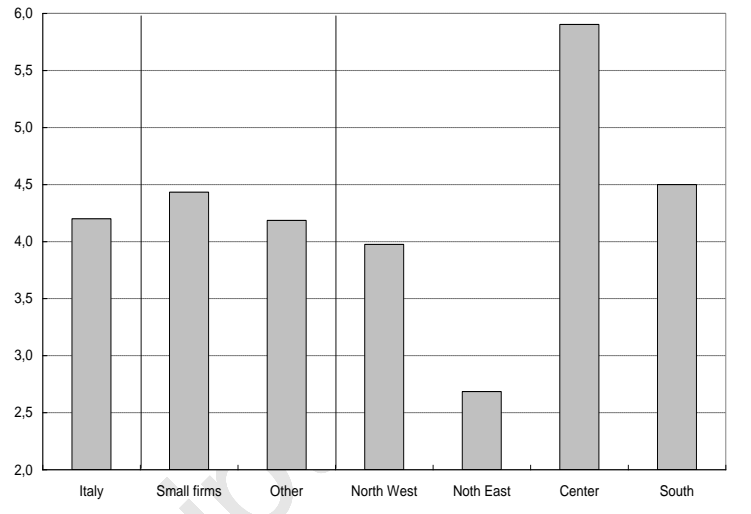

Source: Central Credit Register. See Appendix A.

(1) The $x$-axis is a mobility index. The $y$-axis is a credit quality net deterioration / net improvement index, which ranges from -1 (maximum net deterioration) to +1 (maximum net improvement). See Appendix A. - (2) The Euclidean distance $\mathrm{L}^{2}$ between two matrices $\mathrm{P}_{\mathrm{a}}$ and $\mathrm{P}_{\mathrm{b}}$ is the square of the sum of the quadratic differences between each entry in matrix $\mathrm{P}_{\mathrm{a}}$ and the corresponding entry in $\mathrm{P}_{\mathrm{b}}$, divided by $\mathrm{N}^{2}$ (Jafry and Schuermann, 2004).

According to credit risk models, credit pricing should mirror the expected transition matrix. Banks should calibrate risk premiums charged to customers according to the ex ante likelihood that the relationship move to a different impairment situation ${ }^{5}$. As a consequence, the transition matrix makes it possible to gauge how consistently Italian banks have applied this risk management principle. If riskiness has been correctly estimated, interest rates to customers belonging to different entries in transition matrices (ex post) should display a monotonic upward slope on each row (ex ante). The steeper this curve, the stronger will appear the discriminatory capacity of banks to set rates: in fact, a positively sloped interest rate curve on the ex post matrix suggests, with hindsight, that the probabilities of credit worsening estimated ex ante and incorporated in rates closely mirrored the actual transitions.

The Bank of Italy's survey on interest rates covers a large sample of credits included in the CR database (see Appendix A), whose behaviour in terms of estimated transitions are very close to those displayed in Table 2. These data on interest rates can be used to look at the correspondence between credit transitions and pricing. Table 3 presents average rates charged at the initial reference dates (December 2007 and December 2005 respectively) on customers belonging to the

\footnotetext{
In Figure B.1 Italian banks are also classified according to organizational features. The Bank of Italy conducted a survey on a very large sample of Italian banks, asking questions about organizational features such as use of credit rating/scoring systems, and importance of qualitative information or collateral in extending credit, etc. The survey was carried out in two waves, in 2007 and 2010. For details, see Albareto et al. (2008).

5 Crouhy et al. (2000). According to Jarrow et al. (1997) risk premia should be proportional to the probability that corporate credit evolves towards the worst state (the "absorption" state), starting from the situation at the reference date.
} 
entries of the transition matrices. In other words, Table 3 fills ex ante rates into the ex post matrices.

First, the rates distribution complies - to a large extent - with the implications of the risk models on correct credit pricing. In particular, the first row of the matrix, comprising loans which were fully regular at the starting date, displays a clear upward slope in connection with the situation of the credit relationship after two years. For instance, in December 2007 fully regular loans to firms which would have stayed regular in the subsequent 24 months paid an average of 7.11 per cent. At the same time, fully regular loans set to deteriorate to sub-standard paid 8.37 per cent, those heading towards non-performing paid 9.01 per cent, and future losses paid 9.11 per cent (with a spread of 126bp, 190bp and 200bp, in the order). The same pattern can be observed for end-2005 rates (panel b).

For loans which had already deteriorated before the start of the reference period the curve does not always display a clear positive slope. This confirms that where probabilities of default and correlations are higher, estimating parameters for an appropriate assessment of credit risk is subject to greater uncertainty (Tarashev, 2009).

Table 3

\begin{tabular}{|c|c|c|c|c|c|c|c|}
\hline \multicolumn{8}{|c|}{$\begin{array}{l}\text { Interest rates to firms according to firms' transition } \\
\text { between situations of (non-)impairment(1) } \\
\text { ecember } 2007-2009 \text { and } 31 \text { December } 2005-2007 \text {; percentage rates) }\end{array}$} \\
\hline \multirow{2}{*}{$\begin{array}{l}\text { State of the loan at the } \\
\text { initial date of the } \\
\text { reference period }\end{array}$} & \multicolumn{7}{|c|}{ State of the loan at the final date of the reference period } \\
\hline & $\begin{array}{l}\text { Fully } \\
\text { regular }\end{array}$ & Overdraft & $\begin{array}{l}\text { Past-due } \\
<180 \text { dd }\end{array}$ & $\begin{array}{l}\text { Past-due } \\
>180 \mathrm{dd}\end{array}$ & $\begin{array}{c}\text { Sub- } \\
\text { standard }\end{array}$ & $\begin{array}{c}\text { Non- } \\
\text { performing }\end{array}$ & Loss \\
\hline \multicolumn{8}{|c|}{ Panel a: Interest rates relating to the "Recession" matrix (December 2007 to December 2009} \\
\hline Fully regular & 7.11 & 7.69 & 7.52 & 7.76 & 8.37 & 9.01 & 9.11 \\
\hline Overdraft & 7.81 & 8.03 & 8.48 & 8.55 & 9.12 & 9.89 & 10.25 \\
\hline Past-due $<180$ dd & 8.19 & 8.44 & 8.66 & 8.38 & 9.45 & 9.98 & 10.82 \\
\hline Past-due $>180$ dd & 7.73 & 8.53 & 8.49 & 7.54 & 9.20 & 9.64 & 11.08 \\
\hline Sub-standard & 9.27 & 10.47 & 10.25 & 9.86 & 9.20 & 10.20 & 10.17 \\
\hline Non-performing & & & & & 5.97 & 12.17 & 12.70 \\
\hline Loss & & & & & & 13.65 & 13.65 \\
\hline \multicolumn{8}{|c|}{ Panel b: Interest rates relating to the "Expansion" matrix (December 2005 to December 2007) } \\
\hline Fully regular & 5.95 & 6.59 & 6.42 & 6.59 & 7.92 & 8.08 & 8.61 \\
\hline Overdraft & 6.91 & 7.19 & 7.43 & 7.52 & 7.73 & 9.41 & 9.33 \\
\hline Past-due $<180$ dd & 6.66 & 8.24 & 7.74 & 7.38 & 8.61 & 10.23 & 10.21 \\
\hline Past-due $>180 \mathrm{dd}$ & 7.14 & 7.36 & 6.91 & 7.30 & 8.54 & 10.25 & 9.90 \\
\hline Sub-standard & 7.49 & 8.43 & 6.09 & 8.49 & 8.54 & 9.64 & 9.68 \\
\hline Non-performing & 8.80 & 16.20 & & & 12.88 & 12.95 & 11.06 \\
\hline Loss & & & & & 5.99 & 5.37 & \\
\hline
\end{tabular}

Source: Central Credit Register and Bank of Italy's survey on interest rates. See Appendix A.

(1) Entries in the matrix represent the average interest rates on short-term credit charged by banks at the start of the relevant reference period to Italian firms which, from the state shown in the first column at the beginning of the reference period, would have moved towards the situation shown in the subsequent columns at the end of the following 24 months.

Table 3 shows the ability of banks to discriminate between obligors with different 
prospective riskiness in spite of a similar initial situation and confirms the banks' forward-looking approach. However, the main interest here is to understand how far this capacity was modified by the economic downturn. Figure 2 compares the end-2005 with the end-2007 curve of spreads and suggests that banks were actually surprised by the rapid deterioration in the financial situation of firms. A flatter risk-adjusted interest rate curve for end-2007 rates epitomizes the surprise effect triggered by a crisis whose progress was largely unforeseen, both in intensity and speed ${ }^{6}$.

Figure 2

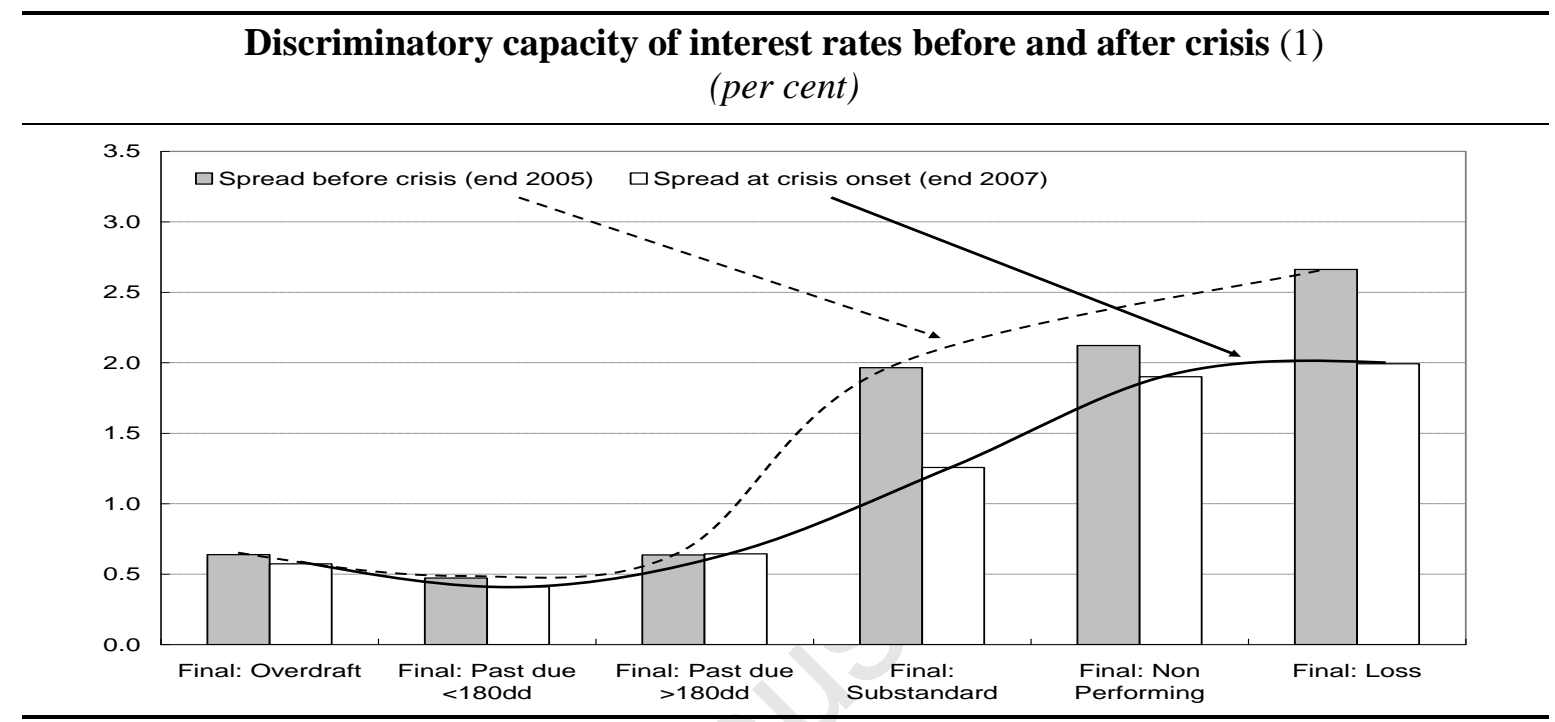

Source: Central Credit Register. See Appendix A.

(1) Spread between (a) average interest rates charged at the end of reference year to firms which would shift from a "fully regular" situation to the state shown on the x-axis within the subsequent 24 months, and (b) average interest rate to firms which would stay in the "fully regular" situation over the same period. The curves are simple graphic interpolations of the bars.

\section{Econometric analysis}

Against the background of a widespread "surprise effect" of the crisis discernible in interest rates (the vertical distance between the curves in Figure 2), the econometric analysis will try to disentangle bank categories for which risk spreads were more affected by the ensuing crisis as regards their ability to account for the actual riskiness of loans, i.e. their possible transition to different impairment states. The baseline equation is:

$$
s_{i, b, t}=f\left(\operatorname{Tr}_{i, b, t}, X_{b}, Z_{i}, \text { Crisis, }\left\lfloor\operatorname{Tr}_{i, b, t} * X_{b} * \text { Crisis }\right\rfloor,\left\lfloor\operatorname{Tr}_{i, b, t} * Z_{i} * \text { Crisis }\right\rfloor\right)
$$

\footnotetext{
The actual unexpected component could be deemed to be even larger, taking into account the higher general level of rates at the end of 2007 compared with the end of 2005. Moreover, the unanticipated component caused by recorded deteriorations or unexpected losses on credits could be under-estimated in the light of the tendency to under-report losses in phases of banking system fragility. Another explanation for the correspondence between interest rates and transition might be self-fulfilling prophecies (i.e. the credit deterioration is driven by the high rates applied). However, the reduced correspondence rates/transitions after the crisis lends weak support to this interpretation, unless one assumes that after the crisis high rates were less able to push customer firms into credit default.
} 
In [1], the dependent variable, $\mathrm{s}_{\mathrm{i}, \mathrm{b}, \mathrm{t}}$ is the rate applied by bank $b$ to firm $i$ at time $t$ ( $t$ assumes two values, the crisis' eve and the untroubled period before the crisis). The rate is expressed as a spread with respect to the average rate applied to non-impaired debtors that maintain the situation at the end of the period. Deducting the average rate applied to non-impaired debtors clears the rate spread from the economy-wide impact of the crisis: the credit spread, in fact, can be decomposed into a systemic risk and an idiosyncratic risk component. The latter, which is partly driven by the impact of the crisis as well, allows us to gauge the 'surprise' effect to heterogeneous banks at the level of single borrowers.

Among the explanatory variables, $\operatorname{Tr}_{\mathrm{i}, \mathrm{b}, \mathrm{t}}$ are dummies for each possible transition between states of impairment for debtor $i$ towards bank $b$ in period $t$ to $t+24$ months (again, the benchmark case regards debtors that are regular at both the start and the end of the relevant period). In fact, the interest rate spread at $t$ results from the combined effect of (a) the initial credit quality status of the loan and (b) the variation in loan quality in the subsequent (24 months) period. By controlling for the component (a), it is possible to disentangle the relationship between interest rate (spread) and the future loan performance (which is unknown to the bank at time $t$ ). The relationship does not suffer from endogeneity, since we control for the initial credit quality status of the loan (the spread at $t$ should already account for the loan performance until $t$, i.e., for the credit quality of the loan at the beginning of the reference period), thus making the loan history prior to $t$ irrelevant. $\mathrm{X}_{\mathrm{b}}$ and $\mathrm{Z}_{\mathrm{i}}$ are controls for bank and firm features, in the order. Some of these features are interacted with both the transition and the crisis dummies, between square brackets in equation [1]. These interactions are a major focus of the analysis in order to detect crisis-related changes in the relationship between ex post transitions and ex ante rates, i.e. to detect a possible weakening in the correct risk-price association. The bank features which are controlled for are size and proxies for the aptitude of banks to gather and employ hard or soft information. The firm features are size, industrial and institutional sector, incorporation technique (e.g. limited company), regional location, length of the firm's credit history, availability of some form of collateral and initial situation of the credit line (see Appendix A). Tables B.2-B.5 report the results for different specifications of the general form of $[1]^{7}$.

A few qualifications are needed before turning to the results. First, the interest rates we use for the econometric exercise are short term rates on overdraft facilities, which are widely acknowledged to be the most suitable kind of rates in order to run comparisons across borrowers (see Berger and Udell, 1995, and Appendix A for details). Second, the lender's reaction to economic distress might well involve quantity tightening in addition to re-pricing. However, possibly reduced amounts of credit should in principle still be priced according to the estimated riskiness of the borrower; moreover, reducing credit lines after the crisis materializes is not a reason for mispricing risky loans before the crisis materializes: this leaves unaffected the research question of the econometric exercise, i.e. the banks' pricing effectiveness. Finally, the way the Italian banks price this type if credit lines (i.e. with frequent revisions of the applied rates) ensures that the observed rate takes into account (i) the general level of rates, driven by the general economic conditions; (ii) the past performance of the loan; (iii) the foreseeable credit quality performance. The model specification allows us to control for all these rate-drivers, in order to enucleate the unexpected component of the credit deterioration.

In principle, the econometric analysis could ask to what extent ex ante interest rates - as an independent variable - are able to predict future transitions via an ordered probit model, much in the vein of Nickell et al. (2000). However, such a setting would yield several effect estimates on every possible transition, whose interpretation would be complex for our purposes. 


\section{Results}

\subsection{Pricing effectiveness and the crisis}

In Table B.2 the basic relationship is first estimated separately for the periods just before the crisis and the preceding untroubled biennium. The parameters of the regressions show that banks (i) do comply with the pricing rules suggested by the credit risk models (most transition dummies have statistically significant coefficients) and (ii) are able to foresee the future evolution of the quality of debtors. The coefficients of the transition dummies follow an upward slope across the matrix rows, often with non-overlapping confidence intervals (Figure 3).

Credits which are already in a non-regular situation at the moment of pricing also command a premium, regardless of their final destination. This is the effect of the greater uncertainty surrounding unstable situations, which is also reflected in less significant coefficients in lower rows of the matrices (Tarashev, 2009). Finally, spreads are decreasing with firm size and if the credit line is assisted by collateral.

The previous remarks hold both before and during the crisis, confirming that banks largely maintained their pricing ability during the turmoil. However, some differences are noteworthy. First, during the crisis the fit of the estimation decreases, pointing to a weaker explanatory power of the credit transitions with respect to the applied interest rate. Second, the slope of the coefficient for worse transitions is milder during the crisis, again suggesting that banks were less sharp at calibrating rates to debtors' actual riskiness.

Figure 3

Estimated risk related interest rate spread before and after the crisis (1) (percentage points)

\begin{tabular}{|c|c|c|c|c|c|c|c|c|c|c|c|c|}
\hline \multirow{2}{*}{$\begin{array}{l}1.9 \\
1.7\end{array}$} & & & & & & & & & & & \multirow[b]{3}{*}{$I$} & \multirow[b]{3}{*}{$I$} \\
\hline & & & & & $I$ &. & & & & & & \\
\hline \multirow[t]{2}{*}{1.5} & & & & $I$ & & & & & & & & \\
\hline & & & & & & & & & & $\Xi$ & & $\perp$ \\
\hline \multirow{2}{*}{1.3} & & & & & & & & & & & & \\
\hline & & & $T$ & & & & & & $I$ & & & \\
\hline 0.9 & & $I$ & & & & & & 1 & & & & \\
\hline \multirow{2}{*}{$\begin{array}{l}0.7 \\
0.5\end{array}$} & $\bar{x}$ & & & & & & $\mathbf{x}$ & & & & & \\
\hline & 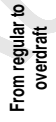 & 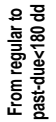 & 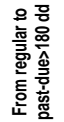 & 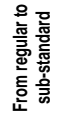 & 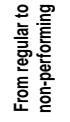 & 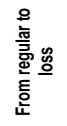 & 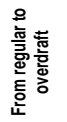 & 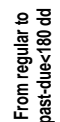 & 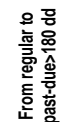 & 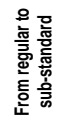 & 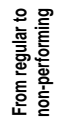 & 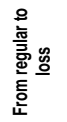 \\
\hline
\end{tabular}

Source: Central Credit Register. See Appendix A.

(1) Estimated coefficients for transition of credits from regular to impaired situations. Each coefficient gauges the spread of regular credits shifted to impaired situations with respect to the average rate applied to credit lines which were regular at both the beginning and the end of the relevant period. Estimation periods are end-2005 to end-2007 (before the crisis), end-2007 to end-2009 (crisis). Vertical lines denote 5 per cent confidence intervals for estimated parameters. 


\subsection{Major banks versus other banks}

The regression in Table B.3 estimates [1], the pivotal specification of this exercise, based on the whole sample. A dummy variable singles out banks belonging to the top five banking groups and is interacted with the crisis indicator. In 2007, the ex ante pricing accuracy of banks was reduced across the board by the ensuing crisis, with an average risk spread reduction of 13 basis points. However, the accuracy of larger banking groups was lessened by far more: the interaction between the dummy for the top five banking groups and the crisis has a coefficient of about -66 basis points, suggesting that bigger banks experienced a large additional decrease in pricing accuracy. Noticeably, the risk-related spread charged by major groups is apparently higher across the whole period (the top five groups' coefficient, not interacted with the crisis, is positive). Major banks experienced troubles in foretelling the future downturn, although their prices were more selective in the untroubled biennium.

In order to shed light on the determinants of the larger unexpected component of credit deterioration for some banks, beyond bank group size, I will now try to disentangle the effect of the aptitude of banks to gather and employ information, either hard (i.e. codified) or soft (i.e. qualitative). To do so, additional regressions consider credit transitions interacted with a set of variables proxying bank features which could affect the ability to price risk, namely (i) the use of rating models (systematically exploiting hard information), (ii) the scope of delegation to loan officers (gathering soft information on-site), and (iii) the intensity of the bank-firm relationship (gathering soft information through interaction). The following sub-sections comment on the results of these specifications (Table B.4).

\subsection{Gathering and using information (1): the adoption of rating models by banks}

In the first column of Table B.4 a dummy identifies banks which had already implemented quantitative rating models in 2007 , i.e. before the crisis. The information is retrieved from the Bank of Italy survey on a large sample of banks (see Appendix A). Rating-users do not show a superior ability to price-discriminate for risk in normal times. However, on the eve of the crisis, banks using rating models show a smaller decrease in the slope of their risk-adjusted interest rate curve (the coefficient of the interaction for use of ratings and the ensuing crisis is positive).

Albareto et al. (2008) find that some banks do not use rating models for pricing, but mainly for screening or monitoring borrowers. Table B.4, column 2, looks at banks which state that their rating models are 'important' or 'fundamental' in credit pricing. These banks do not display superior pricing effectiveness in normal times, but they are less affected by the surprise crisis than other banks. These findings suggest that the crisis magnified the informational improvements stemming from more intense use of hard information (see Panetta et al., 2009).

\subsection{Gathering and using information (2): delegation to loan officers}

Organizational diseconomies of scale can be tackled by banks through a larger autonomy granted to managers directly involved in the relationship with customers (Benvenuti et al., 2010). The Bank of Italy survey gauges the extent of this delegation, by means of an indicator of managers' relative autonomy, i.e. the ratio between (a) the maximum amount of credit a loan officer can grant and (b) the maximum amount the bank's CEO can grant. In column 3 of Table B.4 a dummy variable is equal to 1 if the scope of these delegated powers at the lending bank is above the median value of the sample.

The scope of delegation in normal times does not improve effective pricing of credit. 
However, when a crisis looms, highly decentralized banks seem to be less surprised by upcoming deterioration of their loans as their risk-adjusted interest rate curve stays more upward-sloping. The finding strengthens the soft information argument, as more empowered loan officers should be, in principle, more prone to gather non-codified information.

\subsection{Gathering and using information (3): the intensity of the bank-borrower relationship}

The last column in Table B.4 takes into account the strength of the bank-borrower relationship through the prominent role of the bank among lenders. The main bank dummy takes the value 1 if the bank extends the largest or only loan to the borrower. The main bank benefits from a stronger relationship with the firm and in principle is in a better position to acquire (soft) information about the intrinsic value of the business project. This would enhance its ability to calibrate rates to actual riskiness, even during turmoil. However, a stronger relationship often means a longer one, which could lead to interest rate smoothing along the life of the relationship, thus softening the reaction of rates to a changing credit situation of the borrower.

The results of the estimations shed light on these contrasting views. The dummy for the main bank is negative, which supports the idea that main lenders tend to smooth interest rates across the debtor's riskiness (Machauer and Weber, 1998). Consistently, when faced with a sudden turmoil, the decrease in the risk-related slope for main lenders is smaller, implying that the unexpected component of the credit deterioration is mitigated by the superior information provided by a stronger role of the bank among the firm's lenders.

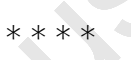

The following table summarizes the main findings of the econometric analysis above.

Table 4

Main results of the econometric analysis

\begin{tabular}{|c|c|c|}
\hline & \multicolumn{2}{|c|}{ Slope of the risk-adjusted interest rate curve (1) } \\
\hline & In untroubled period & On the eve of crisis \\
\hline Larger banking groups & Steeper & Milder \\
\hline Beyond bank size: & & \\
\hline - Use of rating models & $\ldots$ & Steeper \\
\hline - Use of ratings for pricing & $\ldots$ & Steeper \\
\hline - High delegation (decentralization) & $\ldots$ & Steeper \\
\hline - Main bank & Milder & Steeper \\
\hline
\end{tabular}

Source: Econometric analysis. See figures in Appendix B.

(1) Slope of the risk-adjusted interest rate curve for the relevant category of bank, with respect to the average bank, according to econometric estimates reported in figures in Appendix B. Only statistically significant coefficients are reported. 


\subsection{Robustness checks}

In order to check for the robustness of the main findings, some alternative econometric exercises are run on the baseline specification (Table B.5).

First, an alternative explanation of the spread reduction during the crisis is investigated. A milder curve on the crisis' eve could stem not only from credit quality surprises, but also from other sources: during the crisis, some banks could have adopted heavier under-reporting of credit impairment than other banks. In order to check the under-reporting hypothesis, each bank-firm relationship has been assigned to the worst recorded status system-wide, regardless of which classification was reported by the specific lending bank.

Second, an endogeneity issue could arise: banks having some organizational features (e.g. small size or highly decentralized decisions) might select ex ante loans which are easier to price, e.g. because they pertain to segments of borrowers for which information is more crucial, such as smaller borrowers. In order to check for the endogeneity issue, model [1] has been run separately for larger and smaller firms.

Third, certain industries tend to react more to systemic shocks than others, which in turns affect both the level and the variation in their credit risk. As a consequence, variation across banks' pricing may be partly driven by differences in their portfolio composition across different types of industries, rather than by heterogeneity in their ability to price risk. To this end, we have interacted the industry sector of each firm with the crisis period, in order to allow for different impacts of the crisis on the firm's specific business area.

Moreover, the baseline regression was run using as dependent variable interest rates instead of spreads (in fact, according to model [1], the dependent variable in the baseline specification is spreads towards the average rate for the benchmark situation, i.e. the average rate charged to loans that are fully regular at both the start and the end of the period). The estimation was also run excluding fixed effects for banks and allowing for clustering of standard errors by firm, wherever a given firm accounts for multiple observations due to multiple-lending. Spreads outside the $5^{\text {th }}$ and the $95^{\text {th }}$ percentile were excluded, instead of only those beyond the $1^{\text {st }}$ and $99^{\text {th }}$ percentile. Further, some controls were omitted, which might overlap with other factors, such as guaranteed credits or banks' institutional category. Finally, base-line definitions were somewhat refined: impairment status was identified with regard to the credit amount in each impairment status, which entails a stricter definition of overdrafts (see Appendix A), and alternative reference periods were used, i.e. two 30-month periods, June 2008 to December 2010 (crisis) versus December 2005 to June 2008 (untroubled).

All these extensions, apart from an expected decrease in the overall fitting of the estimation, basically yield the same results for relevant parameters (see Table B.5).

\section{Conclusions}

This paper addresses the question of which banks were more affected by the sudden deterioration in credit quality during the crisis as was reflected by the ability of their (ex ante) rates to correctly price (ex post) risk. In order to answer this question, I begin by computing the credit quality transition matrices of bank loans to Italian firms, for the first time to my knowledge.

Matrices changed significantly between expansion and recession. Mobility and distance metrics provide a concrete yardstick of the increase in uncertainty faced by banks in their traditional business owing to the cyclical downturn. Second, banks have been remarkably able to calibrate interest rate spreads to the effective quality of credit as measured by the transition matrix. 
The discriminatory power of spreads remains unquestionable after the crisis surfaces, in spite of greater uncertainty.

The key result is that the crisis made the risk-related curve of rates applied to firms noticeably flatter, as the credit quality worsening often contradicted banks' ex ante credit risk assessments. The unexpected component of the credit worsening is sizeable and depends on the type of bank extending the credit. The unexpected downturn was more serious for the top five Italian groups, suggesting that the pricing effectiveness of banks is affected by the complexity of their governance. Interestingly, larger banks are more able, in general, to tailor ex ante spreads to the actual riskiness of their debtors. In other words, the blurring of their spread structure was the specific outcome of the surprise effect stemming from a rapid unfavourable development .

Looking beyond bank size, the more efficient use of hard information (quantitative rating models) improved pricing performance on the eve of downturn. The geographical or functional distance between decision hubs and local customers might have weakened the ability of some banks to spot the upcoming credit worsening just before the turmoil, and in fact decentralized banks suffered less of a surprise. These findings apparently suggest that the natural experiment provided by the crisis did not drive a wedge between hard information users and decentralised banks: instead, it can be inferred that either a systematic reliance on hard information or a fullfledged relationship lending strategy are both effective, whereas the lack of adoption of a welldefined lending technique leads to poorer pricing performances. Finally, the role of the bankborrower relationship is two-sided: a stronger relationship with borrowers led reference banks (the main banks) to smooth the interest rates-risk relationship in normal times, which also stayed more stable as the downturn approached. 


\section{APPENDIX \\ APPENDIX A: DATA AND METHODOLOGY}

\section{A.1. Data}

\section{A.1.1 Computing the matrices from the Italian Credit Register (CR) data}

Against the background of a conventional 12-month horizon for transition matrices, a 24month period captures the specific dynamics of loan worsening in two stages, which can be labelled pre-crisis (or expansion) and crisis (or recession) situation.

In the matrix, single, non-negative entries sum to 1 by row (right stochastic matrix). The diagonal represents the frequency of keeping the initial state; off-diagonal entries represent the frequency of transition from one state to another, with worsening on the right of the diagonal. The basic assumption behind the cohort approach is that, for a given sample, the probability of a transition from rating $i$ to $j$ is a constant parameter, $p_{i j}$ : for a given initial state, transitions to different possible future states follow a constant parameter, temporally independent process. Estimation can then be performed by taking the fraction of occasions in the sample on which an obligor starts the year in state $i$ and ends it in $j$ (Nickell et al., 2000).

At the initial date of each reference period (i.e. end-2005 and end-2007) a static pool of loans is defined, which are tracked until the end of the relevant period. Transition matrices are computed from the cash credit lines from banks to firms recorded in the CR. Loans larger than 75,000 euros are recorded (30,000 euros from 1 January 2009). All the bank-firm relationships are included with actual credit usage above zero at both (i) the start of the reference period (end-2005, end-2007) and (ii) the end of the reference period (end-2007, end-2009). The state of the loan is observed at the start/end of the period, disregarding the state of the loan at intermediate dates. This entails the loss of a certain number of bank-firm relationships between the start and the end of each period, which therefore do not enter the matrix computation. A bank-firm relationship might be cancelled within a 24-month period due to (i) repayment; (ii) amount reduction below the CR threshold; and (iii) transition to loss and subsequent write-off. With regards to the credit quantities involved, the weight of the non-recorded loans can be estimated at about $18.0 \%$ of total initial credit in the two 24-month periods. Cancellations due to write-off (i.e. situation (iii) above) could cause underestimation of the actual credit worsening. However, this portion should be minor because before write-off a credit is usually recorded in the non-performing category, where the average stay is 54 months. In the reported matrices, loans classified in categories such as "securitized", "debt restructuring", "other", etc, have been overlooked, because in these cases it is unclear how to rank the degree of impairment with respect to other states.

\section{A.1.2 Matrices on the number of positions (bank-firm relationships)}

Frequencies are such that $f_{i j}=n_{i j} / n_{i}$, i.e. the frequency in each cell describing the transition from state $i$ to state $j$ is equal to the number of observations which displayed this migration at the end of the period, divided by the number of observations in the state $i$ at the start of the period. When a credit line is simultaneously classified in different states of impairment, the worst impairment state has been deemed relevant. This approach could affect in particular the "overdraft" classification, which refers to specific credit lines rather than to the overall bank-firm relationship: a given bank-firm relationship is classified as overdraft even if only a minor share of credit belongs to this state of impairment. In order to check for these possible distortions, estimations on credit amount-based matrices use a finer definition of overdraft credit (see below). 


\section{A.1.3 Matrices on the amount of granted and used credit}

Frequencies have also been calculated having regard to loan amounts, attaching a sizeweighted importance to each position. The total credit used within the bank-firm relationship at the reference date is assigned to the worst reported state of impairment, provided that the amount of credit recorded in the relevant state of impairment is at least $10 \%$ of the total used credit (30\% for overdraft). Frequencies in the table refer to the used credit amount at the initial reference date of each period.

\section{A.1.4 Matrices on the number of positions versus credit amounts}

The base-line analysis in the paper refers to matrices calculated on the number of positions. Mobility and improvement/deterioration patterns are similar for matrices based on numbers of bank-firm relationships and on quantities of credit, suggesting that no major differences would emerge from using the latter in the descriptive or econometric analysis. The following table reports the mobility index and the improvement/deterioration indices from the two estimation methods of the transition matrices:

Table A.1

\begin{tabular}{|c|c|c|c|c|}
\hline \multicolumn{5}{|c|}{$\begin{array}{l}\text { Comparison between mobility and deterioration indices, matrices based on number of } \\
\text { bank-firm relationships } v \text { s. Matrices based on quantity of credit (1) }\end{array}$} \\
\hline & \multicolumn{2}{|c|}{ Matrices based on numbers } & \multicolumn{2}{|c|}{ Matrices based on quantities } \\
\hline & 2006-2007 & $2008-2009$ & $2006-2007$ & $2008-2009$ \\
\hline Mobility index & 10.5 & 11.8 & 9.1 & 13.0 \\
\hline Deterioration/improvement & -0.57 & -0.63 & -0.41 & -0.75 \\
\hline
\end{tabular}

(1) Indices are calculated collapsing fully regular loans with overdraft loans. See Appendix A for the method used to calculate the indices.

\section{A.1.5 Definition of absorbing states}

Absorbing states are credit situations in which an improvement is probably not feasible. In a typical transition matrix, this is the default situation. In the CR classification, the absorbing state should be in principle the loss state. Please note that the non-performing state also entails virtually no reversion as it is defined as credit "...towards debtors in a state of insolvency (although not judicially certified) or in substantially comparable situations" in the Bank of Italy's Annual Report. In fact, the CR database records some reversions from the loss state, i.e. bank-firm relationships which are recorded as loss at $t$ and in a non-loss situation at $t+1$. Such cases could occur as a result of (i) erroneous classifications of the firm situation (at $t$ or $t+1$ ); (ii) mergers between banks (e.g. bank $a$, recording debtor $i$ as a loss at $t$, is merged into bank $b$ at $t+l$ and bank $b$ might not record debtor $i$ as a loss at $t+1$ owing to previous relationships with the same debtor: since at each reference date the worst situation is accounted for, debtor $i$ would mark an "improvement from loss" after the merger). The improvements from loss are purely erroneous or fictitious and hence there is no signal from their change between periods. The impact of these unusual transitions is negligible for the purpose of the paper: (i) they account for about $0.3 \%$ of the recorded bank-firm 
relationships in both the periods; and (ii) none of these "reverted" situations is used in the econometric estimation.

\section{A.1.6 Survey statistics on interest rates}

Interest rates are retrieved from banks' survey reports to the Bank of Italy, which cover over 200 banks and a large share of loans to firms. The table below displays the coverage of the interest rate survey with respect to the CR database: interest rates are calculated as the weighted average of simple rates, disregarding fees and commissions. Outlier rates are excluded (below the $1^{\text {st }}$ and $99^{\text {th }}$ percentile). In order to compute averages for end-2005 (end-2007) rates, debtors are classified according to their transition from end-2005 to end-2007 (from end-2007 to end-2009). Small businesses, or SMEs, are defined as firms with less than 20 employed units.

The rates we use are applied to overdraft facilities (i.e. credit lines), as this form of shortterm credit is apt to run comparisons across debtors. The economic conditions of the loan are regularly revised, thus ensuring that reported rates fully reflect the current credit quality of the loan and the general market conditions (i.e., the overdraft interest rate can be equated to a floating rate). The credit lines feature standard agreements and usually do not encompass special covenants, again increasing their comparability. Although the credit lines to which interest rates refer can belong to different vintages, the comparison among rates of different bank-firm couples does not suffer from a vintage bias. In fact, we can assume that rates applied at a given date (end 2005, end 2007) fully reflect both past loan performance and the foreseeable credit quality transition. This allows comparison across bank-firm couples as if the loans had been originated at the same date.

Table A.2

\begin{tabular}{lcc}
\hline \multicolumn{2}{c}{$\begin{array}{c}\text { Average coverage of interest rate data on CR-recorded loans (1) } \\
\text { (per cent) }\end{array}$} \\
\hline & Period Dec. 2005 to Dec. 2007 & Period Dec. 2007 to Dec. 2009 \\
\hline Overall & 43.6 & 43.8 \\
of which: top 5 banking groups & 48.2 & 49.7 \\
SMEs & 37.5 & 37.8 \\
Other firms & 49.1 & 49.2 \\
\end{tabular}

(1) Percentage of bank-firm relationships for which interest rates on short-term bank credit are recorded in the interest rate survey at the initial date of the reference period (December 2005, December 2007) with respect to the corresponding number of bank-firm relationships recorded in the $\mathrm{CR}$ database and used to compute the transition matrix.

\section{A.1.7 Survey on organizational features}

Organizational and lending technology variables are retrieved from the Bank of Italy survey carried out in early 2007 and early 2010 (Albareto et al., 2008).

\section{A.2. Mobility, deterioration and distance indices for matrices}


With respect to the tables in Section 2, mobility indices include some transitions which are not displayed ("restructured loans") because their ranking in terms of degree of deterioration is not univocally defined. Furthermore, slight deteriorations (overdraft) are collapsed with fully regular loans into an "almost regular loans" category as small overdrafts are rather common in Italian bank-firm relationships.

The deterioration/improvement index ranges from 1 (maximum improvement) to -1 (maximum deterioration) and is calculated as follows:

$$
\text { (Improvement - Deterioration) / (Improvement + Deterioration }+ \text { Stability })
$$

where Improvement $=\Sigma_{\mathrm{i}>\mathrm{j}}\left(\mathrm{n}_{\mathrm{ij}}\right)$, Deterioration $=\Sigma_{\mathrm{i}<\mathrm{j}}\left(\mathrm{n}_{\mathrm{ij}}\right)$ and Stability $=\Sigma_{\mathrm{i}=\mathrm{j}}\left(\mathrm{n}_{\mathrm{ij}}\right)$.

A distance metric between two matrices, PA and PB, is labelled L2 (Jafry and Schuermann, 2004): it averages root-mean-square differences between corresponding elements of the matrices:

$$
\mathrm{L}^{2}\left(\mathrm{P}_{\mathrm{A}}, \mathrm{P}_{\mathrm{B}}\right)=\sqrt{ }\left(\sum \sum\left(\mathrm{P}_{\mathrm{A}, \mathrm{i}, \mathrm{j}}-\mathrm{P}_{\mathrm{B}, \mathrm{i}, \mathrm{j}}\right)^{2}\right) / \mathrm{N}^{2}
$$

\section{A.3. Econometric analysis. Variables description}

Dependent variable: spread. - This is the difference between the short-term interest rate applied to any given bank-firm relationship in the sample and the average interest rate applied at the same date to fully regular loans which remained fully regular after 24 months within the same region as the relevant firm.

Transitions. - Dummy variables, $=1$ if the bank-firm relationship has recorded a shift between different credit impairments in the 24 months following the date the interest rate is recorded. Each dummy corresponds to a given cell of the transition matrix ( 49 dummies, e.g. 'From fully regular to fully regular', 'From fully regular to overdraft', etc.).

Credit initial situation. - Dummy variables, $=1$ if the bank-firm relationship starts the reference period in a given state of impairment ( 7 dummies, 'Fully regular', 'Overdraft', 'Past-due $<180$ dd', 'Past-due $>180$ dd', 'Sub-standard', 'Non-performing', 'Loss').

Crisis. Dummy variable, $=1$ for period 2007-09 (interest rates recorded at end-2007, transitions recorded from end-2007 to end-2009).

Top Five banking groups. - Dummy variable, $=1$ if the bank belongs to the 5 largest Italian banking groups.

Firm size. - Logarithm, or square, of the size of bank credit recorded in the dataset of the interest rate survey, proxied by the computational numbers for interest rates charged by all banks to the relevant firm at the relevant date.

SMEs. - Dummy variable,$=1$ for firms with a workforce $<20$ units.

Collateral. - Dummy variables, $=1$ if the bank-firm relationship is assisted by collateral at the start or at the end of the relevant period ( 2 dummies).

Firm's credit history length. - Dummy variables, $=1$ if the firm has been recorded for the first time into the Italian Credit Register in the relevant year (13 dummies, <1995, 1996 to 2007).

Firm's institutional sector. - Dummy variables, $=1$ if the firm belongs to the relevant institutional sector (16 dummies, e.g.: 'operational firms', 'holdings', 'pool of firms', etc.). 
Firm's industry. - Dummy variables, $=1$ if the firm operates in the relevant sector $(192$ dummies).

Firm's region. - Dummy variables, $=1$ if the firm is located in the relevant Italian region (20 dummies).

Firm's incorporation technique. - Dummy variables, $=1$ if the firm is incorporated according to the relevant scheme ( 5 dummies, e.g. 'limited company with equity capital', 'limited company', etc.).

Bank's category. - Dummy variables, $=1$ if the bank belongs to the relevant institutionaldimensional group ( 3 dummies, 'Big, major and medium-sized banks', 'Small banks, not mutual (i.e. not Bcc)', 'Small, mutual banks (Bcc)').

Banks using rating models, using rating model for pricing, with high delegation. - Dummy variables, = 1 if, according to the Bank of Italy's survey (Albareto et al., 2008), banks used rating models for firms in 2007, or used rating models for pricing, or had an above-the-median relative delegation to the loan officer (amount of credit that the loan officer could grant to firms compared with the amount of credit that the CEO could grant).

Main bank. - Dummy variable, $=1$ if the bank extended the largest amount of credit to the relevant firm at the initial date of the relevant period. 


\section{APPENDIX B: TABLES AND FIGURES}

Table B.1

\begin{tabular}{|c|c|c|c|c|c|c|c|c|}
\hline \multicolumn{9}{|c|}{$\begin{array}{l}\text { Transition matrix (credit amounts) (1) } \\
\text { (period 31 December 2007-2009 and 2005-2007; percentage frequencies) }\end{array}$} \\
\hline \multirow{3}{*}{$\begin{array}{l}\text { State of the loan } \\
\text { at the initial date } \\
\text { of the reference } \\
\text { period }\end{array}$} & \multicolumn{7}{|c|}{ State of the loan at the final date of the reference period } & \multirow[b]{2}{*}{$\begin{array}{l}\text { Amount of } \\
\text { loans }(€ \\
\text { mn })\end{array}$} \\
\hline & $\begin{array}{l}\text { Fully } \\
\text { regular }\end{array}$ & Overdraft & $\begin{array}{l}\text { Past-due } \\
<180 \text { dd }\end{array}$ & $\begin{array}{l}\text { Past-due } \\
>180 \text { dd }\end{array}$ & $\begin{array}{c}\text { Sub- } \\
\text { standard }\end{array}$ & $\begin{array}{l}\text { Non- } \\
\text { performin } \\
\mathrm{g}\end{array}$ & Loss & \\
\hline & \multicolumn{8}{|c|}{ Panel a. "Recession" matrix (December 2007 to December 2009) } \\
\hline Fully regular & 89.3 & 1.1 & 1.6 & 1.8 & 3.9 & 2.0 & 0.4 & $610,629.6$ \\
\hline Overdraft & 78.6 & 4.0 & 1.9 & 2.1 & 6.5 & 4.1 & 2.8 & $6,027.6$ \\
\hline Past-due $<180$ dd & 57.8 & 1.1 & 5.4 & 5.8 & 16.7 & 12.4 & 0.7 & $7,342.3$ \\
\hline Past-due $>180 \mathrm{dd}$ & 55.8 & 0.6 & 2.7 & 9.1 & 19.4 & 11.8 & 0.6 & $7,702.3$ \\
\hline Sub-standard & 14.1 & 0.3 & 0.8 & 1.2 & 40.7 & 39.2 & 3.7 & $9,571.5$ \\
\hline Non-performing & 0.2 & 0.0 & 0.0 & 0.0 & 0.1 & 93.8 & 5.8 & $17,935.2$ \\
\hline \multirow[t]{2}{*}{ Loss } & 0.3 & 0.0 & & & 1.4 & 3.6 & 94.7 & $4,248.1$ \\
\hline & \multicolumn{8}{|c|}{ Panel b. "Expansion" matrix (December 2005 to December 2007) } \\
\hline Fully regular & 93.7 & 1.3 & 1.2 & 1.3 & 1.4 & 1.0 & 0.2 & $492,580.3$ \\
\hline Overdraft & 83.2 & 7.3 & 1.3 & 2.0 & 2.7 & 2.9 & 0.5 & $5,953.6$ \\
\hline Past-due $<180$ dd & 70.7 & 1.1 & 5.3 & 7.3 & 7.9 & 6.9 & 0.8 & $7,396.7$ \\
\hline Past-due $>180$ dd & 61.3 & 1.0 & 3.8 & 12.3 & 12.5 & 8.7 & 0.5 & $10,036.6$ \\
\hline Sub-standard & 16.4 & 0.3 & 1.0 & 1.6 & 40.0 & 36.0 & 4.7 & $9,319.1$ \\
\hline Non-performing & 0.3 & 0.1 & 0.0 & 0.0 & 0.2 & 92.1 & 7.2 & $19,161.7$ \\
\hline Loss & 0.4 & 0.0 & & 0.0 & 0.0 & 8.6 & 90.9 & $8,222.2$ \\
\hline
\end{tabular}

Source: Central Credit Register. See Appendix A.

(1) Entries in the matrix represent the percentage frequencies at which the credit amounts relating to each bank-firm relationship recorded in the state shown in the first column at the start of the reference period moved towards the situation shown in the subsequent columns at the end of the following 24 months. Frequencies are reported as percentage of the number of bank-firm relationships in the sample belonging to the relevant initial state; they sum to 1 by row. Values below 0.1 are not reported. 
Table B.2

\section{Impact of the crisis on credit risk pricing (1)}

dependent variable: interest rate spread towards regular loans at start and end of the relevant period

\begin{tabular}{|c|c|c|c|c|c|c|c|}
\hline \multirow[b]{2}{*}{ Transitions: (2) } & \multicolumn{7}{|c|}{ Panel [1] Before the crisis (2005-07) } \\
\hline & 1. & 2. & 3. & 4. & 5. & 6. & 7. \\
\hline 1. from regular loans & & 0.66 & 0.82 & 0.95 & 1.59 & 1.72 & 1.67 \\
\hline 2. from overdraft & 0.35 & 0.88 & 1.01 & 1.16 & 1.68 & 1.85 & 1.93 \\
\hline 3. from past-due $<180 \mathrm{dd}$ & -0.71 & -0.12 & & -0.02 & 0.64 & 0.79 & 0.84 \\
\hline 4. from past-due $>180 \mathrm{dd}$ & -0.57 & 0.01 & & 0.07 & 0.84 & 1.07 & 1.34 \\
\hline 5. from sub-standard & -0.39 & -0.03 & -0.08 & & -0.18 & 0.19 & 0.24 \\
\hline 6. from non-performing & & & & & & & 0.66 \\
\hline
\end{tabular}

Initial credit situation:

2. overdraft

3. past-due $<180 \mathrm{dd}$

4. past-due $>180 \mathrm{dd}$

5. sub-standard

6. non-performing

Top five banking groups

Firm size (log)

Firm size (squared)

Non-SMEs

Collateral - start period

$$
\text { - end period }
$$

Firm credit history length

Firm institutional sector

Firm industry

Firm region

Firm incorporation technique

Bank category

Bank fixed effects

Constant

N. observations

Adj. R-squared
YES

YES

YES

YES

YES

0.591

$1.883^{* * *}$

$1.850^{\star \star *}$

2.523 ***

$1.954^{* * *}$

0.411

$-0.192$

$-0.002$

0.084

-0.047 **

$-0.063$

YES

YES

$6.533^{* \star *}$

596,717

0.29 
Source: estimation of regressions based on equation [1] in Section 3.

$(1) *=$ significant at $10 \% ; * *=$ significant at $5 \% ; * * *=$ significant at $1 \%$. Missing values mean that the estimation is not possible for the relevant parameter. Interest rates outside the $1^{\text {st }}$ or $99^{\text {th }}$ percentile are dropped. - (2) The reported coefficients refer to the spread of loans shifting from the situation in the first column to the situations in the subsequent columns, labelled as follows: 1 . regular 2 . overdraft, 3. past-due $<180 \mathrm{dd}$, 4. past-due $>180 \mathrm{dd}$, 5. sub-standard, 6. non-performing, 7. loss. Figures in bold denote parameters statistically significant at least at the $1 \%$ or $5 \%$ level. 
Table B.2 (continued)

\section{Impact of the crisis on credit risk pricing (1)}

dependent variable: interest rate spread towards regular loans at start and end of the relevant period

\begin{tabular}{|c|c|c|c|c|c|c|c|}
\hline \multirow[b]{2}{*}{ Transitions: (2) } & \multicolumn{7}{|c|}{ Panel [2] During the crisis (2007-09) } \\
\hline & 1. & 2. & 3. & 4. & 5. & 6. & 7. \\
\hline 1. from regular loans & & 0.67 & 0.85 & 1.06 & 1.37 & 1.53 & 1.51 \\
\hline 2. from overdraft & -1.53 & -0.99 & -0.82 & -0.70 & -0.38 & -0.17 & \\
\hline 3. from past-due $<180 \mathrm{dd}$ & -1.57 & -1.10 & -1.06 & -0.93 & -0.48 & -0.28 & \\
\hline 4. from past-due $>180 \mathrm{dd}$ & -0.73 & -0.24 & & -0.09 & 0.46 & 0.68 & 0.95 \\
\hline 5. from sub-standard & -0.39 & -0.09 & & 0.04 & -0.15 & 0.21 & 0.32 \\
\hline 6. from non-performing & & & & & & 5.73 & \\
\hline
\end{tabular}

Initial credit situation:

2. overdraft

3. past-due $<180 \mathrm{dd}$

$2.482^{* * *}$

4. past-due $>180 \mathrm{dd}$

$2.820 * * *$

5. sub-standard

$1.961^{* * *}$

6. non-performing

2.408 ***

Top five banking groups

$-1.353^{* * \star}$

Firm size (log)

$-0.055$

Firm size (squared)

$-0.008$

Non-SMEs

0.103

Collateral - start period

$-0.020$

- end period

Firm credit history length

YES

Firm institutional sector

YES

Firm industry

YES

Firm region

YES

Firm incorporation technique

YES

Bank category

YES

Bank fixed effects

YES

Constant

$4.499^{* * *}$

N. observations

682,246

Adj. R-squared

0.27 
Source: estimation of regressions based on equation [1] in Section 3.

(1) $*=$ significant at $10 \%$; $* *=$ significant at $5 \%$; *** = significant at $1 \%$. Missing values mean that the estimation is not possible for the relevant parameter. Interest rates outside the $1^{\text {st }}$ or $99^{\text {th }}$ percentile are dropped. $-(2)$ The reported coefficients refer to the spread of loans shifting from the situation in the first column to the situations in the subsequent columns, labelled as follows: 1 . regular 2 . overdraft, 3. past-due $<180 \mathrm{dd}$, 4. past-due $>180 \mathrm{dd}$, 5. sub-standard, 6. non-performing, 7. loss. Figures in bold denote parameters statistically significant at least at the $1 \%$ or $5 \%$ level.

Table B.3

Impact of the crisis on credit risk pricing: top five groups (1)

dependent variable: interest rate spread towards regular loans at start and end of the period

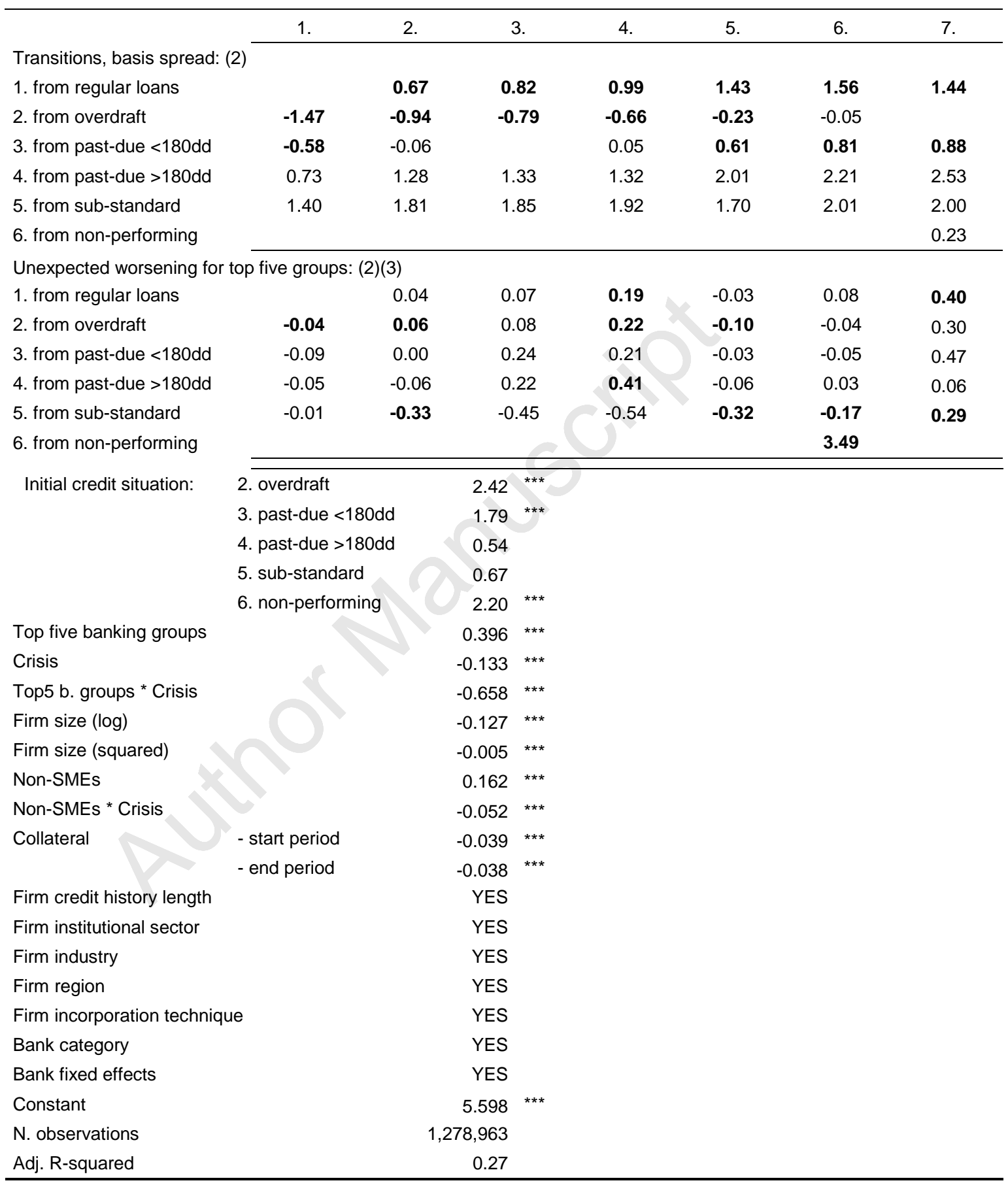

Source: estimation of regressions based on equation [1] in Section 3. 
(1) $*$ = significant at $10 \%$; $*$ = significant at $5 \%$; *** = significant at $1 \%$. Missing values mean that the estimation is not possible for the relevant parameter. Interest rates outside the $1^{\text {st }}$ or $99^{\text {th }}$ percentile are dropped. - (2) The reported coefficients refer to the spread of loans shifting from the situation in the first column to the situations in the subsequent columns, labelled as follows: 1 . regular 2 . overdraft, 3. past-due <180 dd, 4. past-due >180 dd, 5. sub-standard, 6. non-performing, 7. loss. Figures in bold denote parameters statistically significant at least at the $1 \%$ or $5 \%$ level. - (3) The coefficients estimate the interaction of the transition dummies $*$ top five groups * Crisis, and gauge the differential unexpected component of the credit worsening, as reflected in credit risk pricing efficiency, for the top five groups.

Table B.4

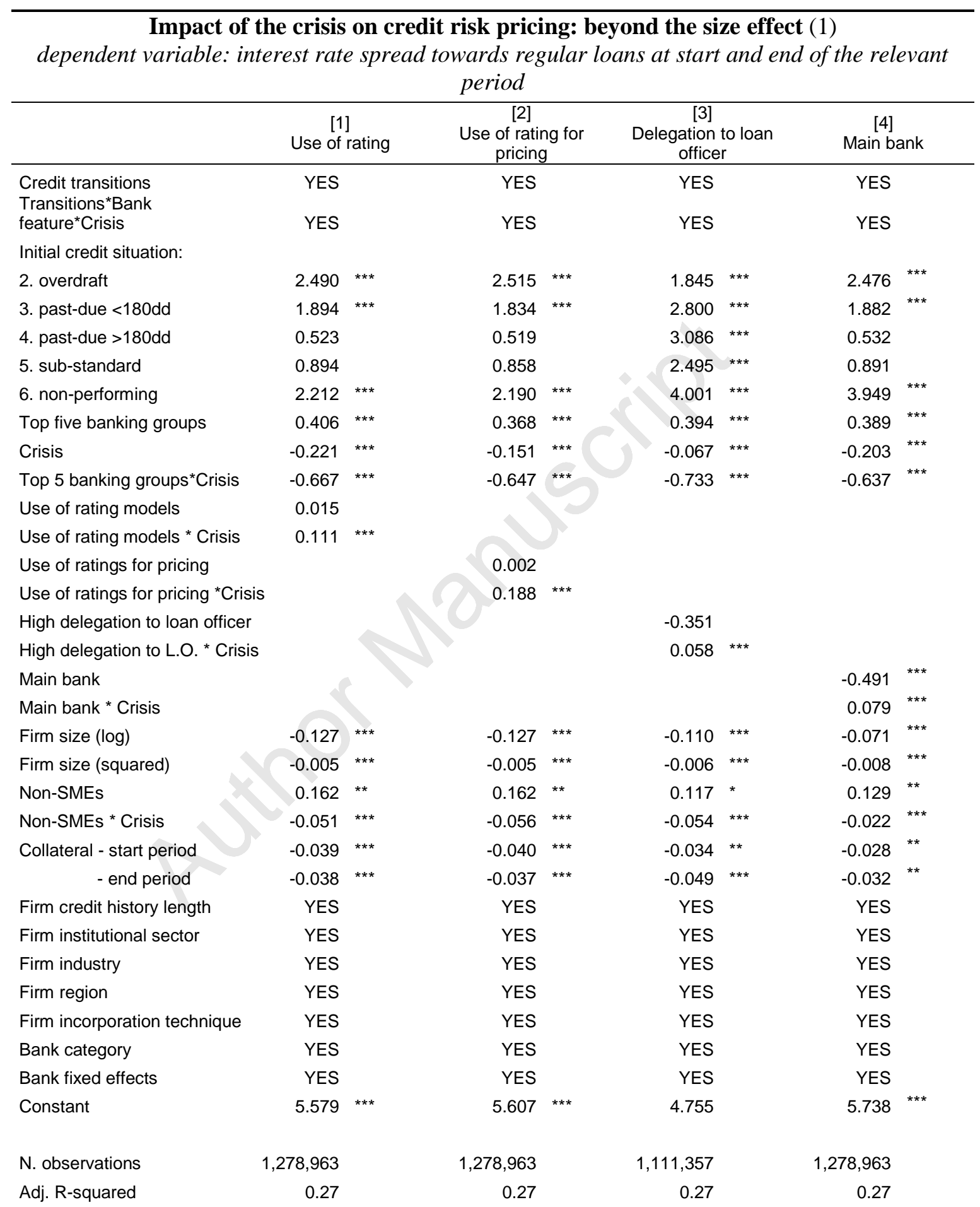


Source: estimation of regressions based on equation [1] in Section 3.

$*=$ significant at $10 \% ; * *=$ significant at $5 \% ; * * *=$ significant at $1 \%$. Missing values mean that the estimation is not possible for the relevant parameter. Interest rates outside the $1^{\text {st }}$ or $99^{\text {th }}$ percentile are dropped. 
Table B.5

\begin{tabular}{|c|c|c|c|c|c|c|c|c|}
\hline $\begin{array}{l}\text { Impact of } \\
\text { dependent variable: inter }\end{array}$ & $\begin{array}{l}\text { the crisi } \\
\text { rest rate }\end{array}$ & $\begin{array}{l}\text { S on cr } \\
\text { or sprec }\end{array}$ & $\begin{array}{l}\text { it risk pr } \\
\text { towards } r \\
\text { period }\end{array}$ & $\begin{array}{l}\text { icing: } \\
\text { egulat }\end{array}$ & $\begin{array}{l}\text { obustness } \\
\text { oans at st }\end{array}$ & $\begin{array}{l}\text { check } \\
\text { art and }\end{array}$ & 1) of the $r$ & elevant \\
\hline & $\begin{array}{r}\text { Robustnes } \\
\text { (a) }\end{array}$ & s check & $\begin{array}{r}\text { Robustnes } \\
\text { (b) }\end{array}$ & s check & $\begin{array}{r}\text { Robustnes } \\
\text { (c) }\end{array}$ & ss check & $\begin{array}{r}\text { Robustnes } \\
\text { (d) }\end{array}$ & s check \\
\hline Credit transitions & YES & & YES & & YES & & YES & \\
\hline Credit transitions ${ }^{\star}$ Topfive ${ }^{*}$ Crisis & YES & & YES & & YES & & & \\
\hline Initial credit situation: & & & & & & & & \\
\hline 2. overdraft & 2.417 & $* * *$ & 2.543 & $* \star *$ & 2.418 & $* * *$ & 2.424 & $* * *$ \\
\hline 3. past-due $<180 \mathrm{dd}$ & 1.790 & $* * *$ & 1.874 & $* * *$ & 1.790 & *** & 1.807 & $* * *$ \\
\hline 4. past-due $>180 \mathrm{dd}$ & 0.539 & & 0.489 & & 0.576 & & 0.621 & \\
\hline 5. sub-standard & 0.706 & $* * *$ & 0.766 & $* * *$ & .0780 & $* * *$ & 0.763 & $* * *$ \\
\hline 6. non-performing & 2.204 & $* * *$ & 1.178 & $* * *$ & 2.186 & *** & 2.191 & $* * *$ \\
\hline Top five banking groups & 0.407 & $* * *$ & 0.752 & $* * *$ & 0.393 & $* * *$ & 0.403 & *** \\
\hline Crisis & -0.125 & $* * *$ & -0.293 & $* * *$ & 0.025 & & 1.043 & $* * *$ \\
\hline Top five b.ing groups ${ }^{*}$ Crisis & $-0.667 *$ & & -0.194 & $* * *$ & -0.659 & $* * *$ & & $* * *$ \\
\hline Firm size $(\log )$ & -0.127 & $* * *$ & -0.128 & $* * *$ & -0.127 & $* * *$ & -0.129 & $* * *$ \\
\hline Firm size (squared) & -0.005 & $* * *$ & -0.005 & $* * *$ & -0.005 & $* \star *$ & -0.005 & $* * *$ \\
\hline Non-SMEs & 0.162 & $* * *$ & 0.265 & $* \star *$ & 0.157 & ** & 0.176 & $* * \star$ \\
\hline Non-SMEs * Crisis & -0.052 & $* * *$ & -0.100 & $* * *$ & -0.043 & *** & -0.074 & $* * *$ \\
\hline Collateral - start period & -0.039 & $* \star \star$ & -0.043 & *** & -0.039 & *** & -0.042 & *** \\
\hline - end period & -0.038 & $* * *$ & -0.047 & $* * *$ & -0.039 & *** & -0.037 & *** \\
\hline Firm credit history length & YES & & YES & & YES & & YES & \\
\hline Firm institutional sector & YES & & YES & & YES & & YES & \\
\hline Firm industry & YES & & YES & & & & YES & \\
\hline Firm industry * Crisis & & & & & YES & & & \\
\hline Firm region & YES & & YES & & YES & & YES & \\
\hline Firm incorporation technique & YES & & YES & & YES & & YES & \\
\hline Bank category & NO & & NO & & YES & & YES & \\
\hline Bank fixed effects & YES & & NO & & YES & & YES & \\
\hline Constant & 5.589 & $* * *$ & 4.595 & $* * *$ & 5.780 & *** & 11.713 & *** \\
\hline N. observations & $1,278,963$ & & $1,278,963$ & & $1,278,963$ & & $1,278,963$ & \\
\hline Adj. R-squared & 0.27 & & 0.21 & & 0.27 & & 0.24 & \\
\hline
\end{tabular}

Source: estimation of regressions based on equation [1] in Section 3.

(1) $*$ significant at $10 \%$; $* *=$ significant at $5 \%$; $* * *=$ significant at $1 \%$. Missing values mean that the estimation is not possible for the relevant parameter. Each column refers to a different modification of the baseline specification in equation [1]: Column (a): bank category excluded; (b): bank category excluded and non-fixed effect for banks; (c): industry-time-varying effects added; (d): dependent variable $=$ interest rates not spread towards the benchmark case (i.e. the average rate to firms whose loans were in a regular situation both at the start and at the end of the relevant period). 
Table B.5 (continued)

\begin{tabular}{|c|c|c|c|c|c|c|}
\hline \multicolumn{7}{|c|}{$\begin{array}{c}\text { Impact of the crisis on credit risk pricing: robustness c } \\
\text { dependent variable: interest rate or spread towards regular loans at star } \\
\text { period }\end{array}$} \\
\hline & \multicolumn{2}{|c|}{ Robustness check (e) } & \multicolumn{2}{|c|}{ Robustness check (f) } & \multicolumn{2}{|c|}{ Robustness check (g) } \\
\hline Credit transitions & YES & & YES & & YES & \\
\hline Credit transitions ${ }^{*}$ Topfive ${ }^{*}$ Crisis & YES & & YES & & YES & \\
\hline \multicolumn{7}{|l|}{ Initial credit situation: } \\
\hline 2. overdraft & 0.771 & $* * *$ & 1.405 & *** & 0.484 & $* * *$ \\
\hline 3. past-due $<180 \mathrm{dd}$ & 2.415 & $* * *$ & -0.331 & & 0.456 & $* * *$ \\
\hline 4. past-due $>180 \mathrm{dd}$ & 1.678 & $* * *$ & 1.156 & *** & 0.597 & $* * *$ \\
\hline 5. sub-standard & 2.316 & $* * *$ & 1.994 & *** & 0.192 & $* * *$ \\
\hline 6. non-performing & 1.839 & $* * *$ & 1.241 & & -0.121 & \\
\hline Top five banking groups & 0.098 & $* * *$ & -0.599 & *** & 0.421 & $* \star *$ \\
\hline Crisis & -0.499 & $* * *$ & -0.017 & ** & -0.217 & $\star * *$ \\
\hline Top five banking groups ${ }^{\star}$ Crisis & -0.338 & $* \star *$ & -0.337 & $\star \star \star *$ & -0.655 & $\star \star \star *$ \\
\hline Firm size $(\log )$ & -0.120 & $* * *$ & 0.299 & *** & -0.027 & $* * *$ \\
\hline Firm size (squared) & -0.004 & $* * *$ & -0.013 & *** & -0.010 & $* * *$ \\
\hline Non-SMEs & 0.179 & $* * *$ & 0.046 & & 0.124 & * \\
\hline Non-SMEs * Crisis & -0.125 & $* * *$ & 0.005 & & -0.026 & $* * *$ \\
\hline Collateral - start period & -0.027 & ** & -0.065 & $* * *$ & -0.032 & $* * *$ \\
\hline - end period & -0.052 & 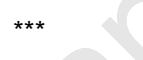 & NO & & -0.038 & $\star * *$ \\
\hline Firm credit history length & YES & Ne & YES & & YES & \\
\hline Firm institutional sector & YES & & YES & & YES & \\
\hline Firm industry & YES & & YES & & YES & \\
\hline Firm region & YES & & YES & & YES & \\
\hline Firm incorporation technique & YES & & YES & & YES & \\
\hline Bank category & YES & & YES & & YES & \\
\hline Bank fixed effects & YES & & YES & & YES & \\
\hline Constant & 5.571 & $* * *$ & 0.342 & & 5.184 & $* * *$ \\
\hline N. observations & $1,186,593$ & & $1,161,899$ & & $1,278,963$ & \\
\hline Adj. R-squared & 0.26 & & 0.16 & & 0.28 & \\
\hline
\end{tabular}

Source: estimation of regressions based on equation [1] in Section 3.

(1) $*=$ significant at $10 \%$; $* *=$ significant at $5 \%$; *** = significant at $1 \%$. Missing values mean that the estimation is not possible for the relevant parameter. Each column refers to a different modification of the baseline specification in equation [1]: Column (e): excluded outlier observations with spreads beyond the $5^{\text {th }}$ and $95^{\text {th }}$ percentile. Estimates for coefficient of the transition matrices and the same coefficients interacted with the crisis variable are omitted. (f): impairment situations for each bank-firm relationship are defined according to the quantities of credit in each situation at the reference date (see Appendix A, Data and methodology). The reference periods are December 2005-June 2008 (non-crisis), June 2008-December 2010 (crisis). (g): the impairment situation is defined having regard to the worst recorded classification of the debtor in the CR database at the reference date, regardless of which bank had provided the worst classification. 
Table B.5 (end)

\begin{abstract}
Impact of the crisis on credit risk pricing: robustness checks (small and non-small firms) (1) dependent variable: interest rate spread towards regular loans at start and end of the relevant
\end{abstract} period

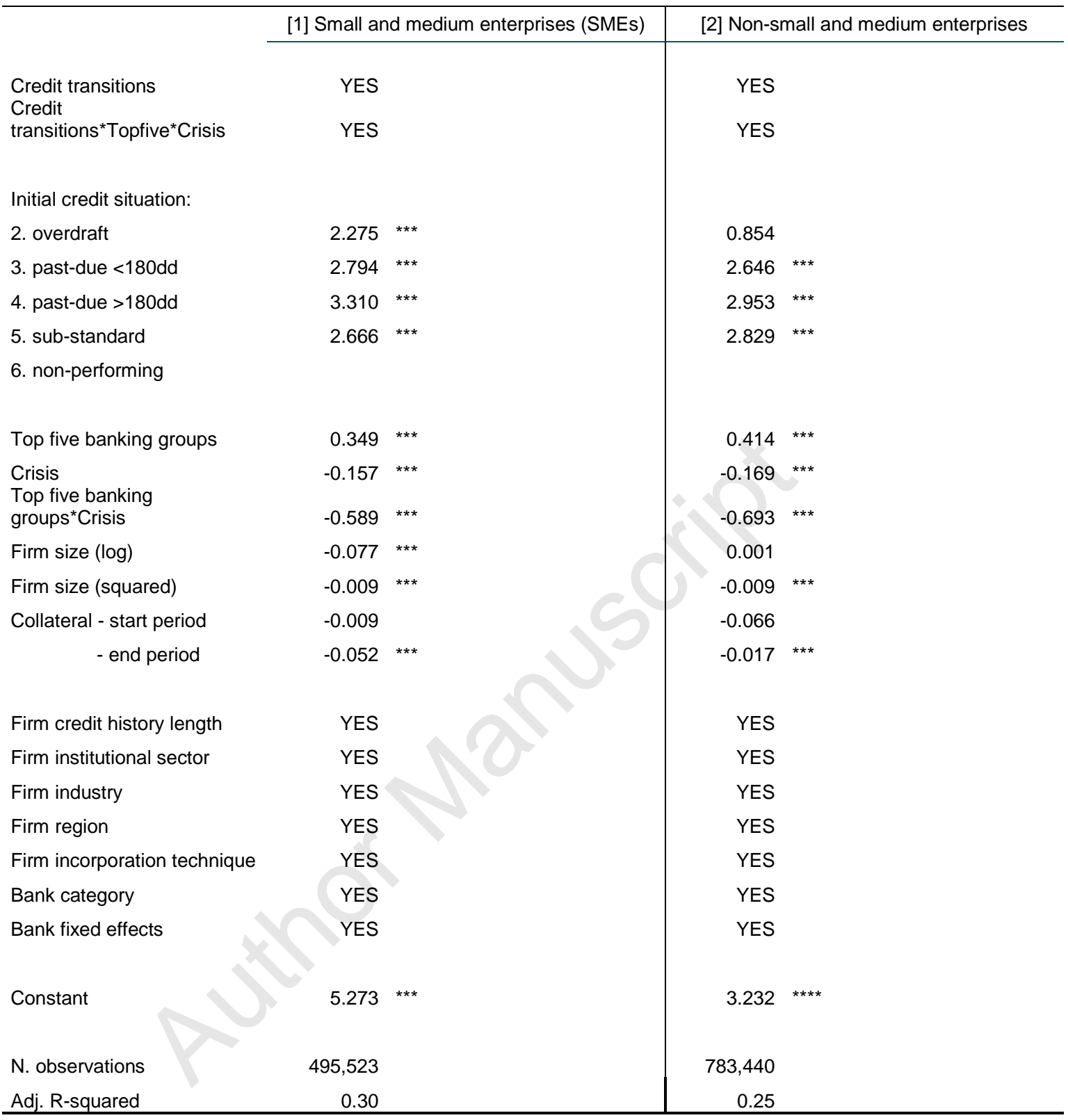

Source: estimation of regressions based on equation [1] in the text.

(1) $*$ significant at $10 \%$; ** = significant at $5 \%$; *** = significant at $1 \%$. Missing values mean that the estimation is not possible for the relevant parameter. Interest rates outside the $1^{\text {st }}$ or $99^{\text {th }}$ percentile are dropped. Small firms are firms with up to 20 employees. $-(2)$ The reported coefficients refer to the spread of loans shifting from the situation in the first column to the situations in the subsequent columns, labelled as follows: 1 . regular 2. overdraft, 3. past-due $<180 \mathrm{dd}$, 4 . past-due $>180 \mathrm{dd}, 5$. sub-standard, 6 . non-performing, 7 . loss. Figures in bold denote parameters statistically significant at least at the $1 \%$ or $5 \%$ level. - (3) The coefficients estimate the interaction of the transition dummies * banks within the top five groups * Crisis, and gauge the differential unexpected component of the credit worsening, as reflected in credit risk pricing efficiency, for banks in the top five groups. 
Figure B.1

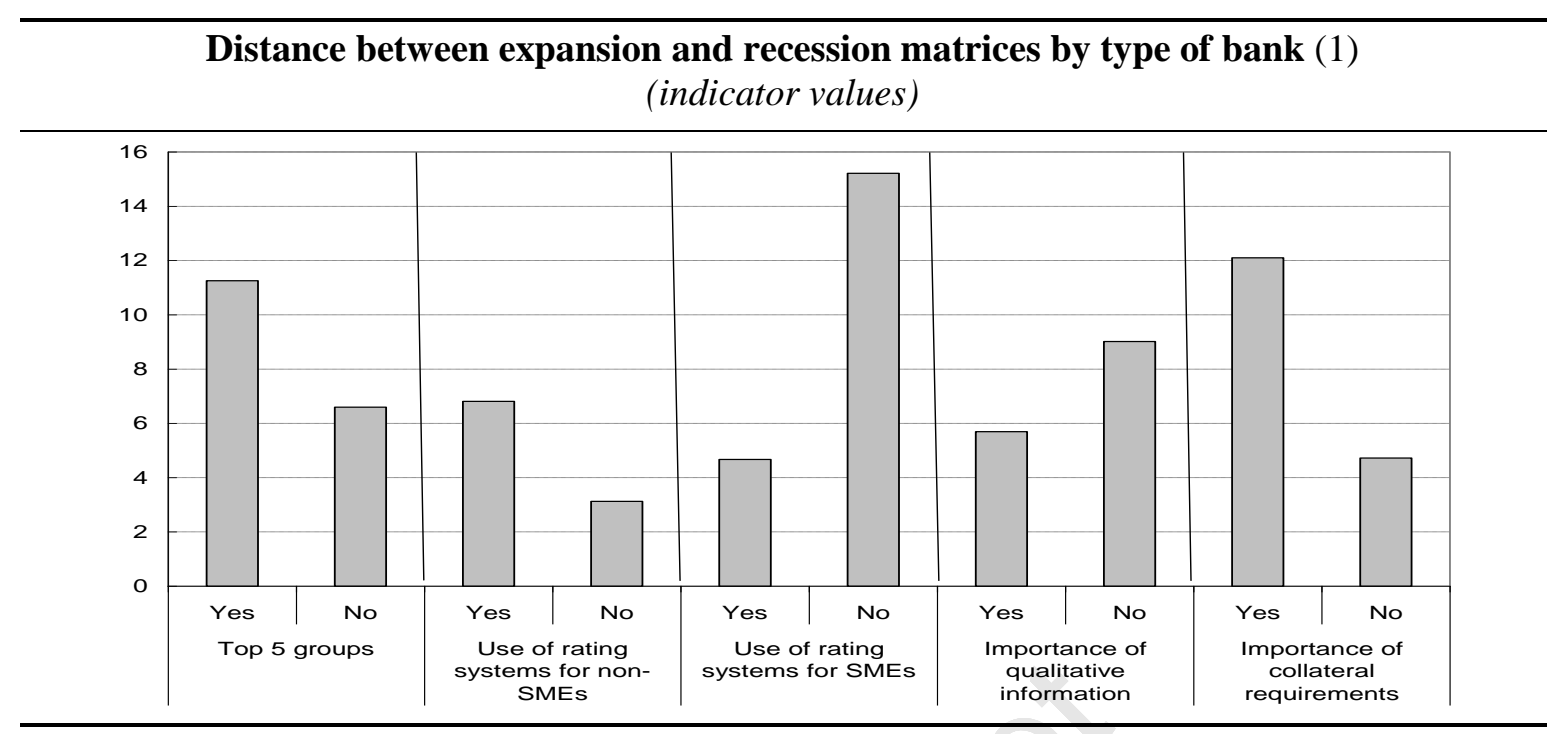

Sources: Central Credit Register, banks' supervisory reports, Bank of Italy organizational survey of banks. See Appendix A

(1) Euclidean distance $L^{2}$ between two matrices $P_{a}$ and $P_{b}$ is the square of the sum of the quadratic differences between each entry in matrix $\mathrm{P}_{\mathrm{a}}$ and the corresponding entry in $\mathrm{P}_{\mathrm{b}}$, divided by $\mathrm{N}^{2}$ (Jafry and Schuermann, 2004). Apart from bank size, banks are classified according to a survey run by the Bank of Italy in 2007 and 2010 


\section{REFERENCES}

Albareto, G., Benvenuti, M., Mocetti, S., Pagnini, M., Rossi, P., 2008. Lending organizational structure and the use of credit scoring: Evidence from a survey on Italian banks. Bank of Italy Occasional Paper 12.

Altman, E.I., 1998. The importance and subtlety of credit rating migration. Journal of Banking and Finance 22, 1231-1247.

Amato, J., Remolona, E., 2005. The pricing of unexpected credit losses. BIS Working Papers 190.

Bangia, A., Diebold, F.X., Kronimus, A., Schagen, C., Schuermann, T., 2002. Ratings migration and the business cycle, with applications to credit portfolio stress testing. Journal of Banking and Finance 26, 445-474.

Benvenuti, M., Casolaro, L., Del Prete, S., Mistrulli, P.E., 2010. Loan officer authority and small business lending. Evidence from a survey. In: Banca d'Italia, Banks, local credit markets and credit supply, Workshops and Conferences 5.

Berger, A.N., Frame, W.S., Miller, N.H., 2002. Credit scoring and the availability, price, and risk, of small business credit. Federal Reserve Bank of Atlanta Working Paper 2002-6.

Berger, A.N., Miller, N.H., Petersen, M.A., Rajan, R.G., Stein, J.C., 2005. Does function follow organizational form? Evidence from the lending practices of large and small banks. Journal of Financial Economics 76 (2), 237-269.

Berger, A.N., Udell, G.F., 1995. Relationship lending and lines of credit in small firm finance. Journal of Business, 68 (3) (Jul., 1995), 351-381.

Bofondi, M., Gobbi, G., 2004. Bad loans and entry into local credit markets. Bank of Italy Working Paper 509.

Crouhy, M., Galai, D., Mark, R., 2000. A comparative analysis of current credit risk models. Journal of Banking and Finance 24, 57-117.

Gobbi, G., Lotti, F., 2004. Entry decisions and adverse selection: An empirical analysis of local credit markets. Bank of Italy Working Paper 535.

Hancock, D., Wilcox, J., 1998. The 'credit crunch' and the availability of credit to small business. Journal of Banking and Finance 22, 983-1014.

Hauswald, R., Marquez, R., 2006. Competition and strategic information acquisition in credit markets. Review of Financial Studies 3, 967-1000.

Jafry, Y., Schuermann, T., 2004. Measurement, estimation and comparison of credit migration matrices. Journal of Banking and Finance 28, 2603-2639.

Jarrow, R.A., Lando, D., Turnbull, S.M., 1997. A Markov model for the term structure of credit risk spreads. The Review of Financial Studies 10 (2), 481-523.

Kashyap, A.K., Stein, J.C., 2004. Cyclical implications of the Basel II capital standards. Economic Perspectives, Federal Reserve Bank of Chicago 1q/2004, 18-31.

Lando, D., Skodeberg, T., 2002. Analyzing rating transitions and rating drift with continuous observations. Journal of Banking and Finance 26, 423-444.

Machauer, A., Weber, M., 1998. Bank behavior based on internal credit ratings of borrowers. CFS Working Paper 98/08

Nickell, P., Perraudin, W., Varotto, S., 2000. Stability of rating transitions. Journal of Banking and 
Finance 124, 203-227.

Panetta, F., Schivardi, F., Shum, M., 2009. Do mergers improve information? Evidence from the loan market. Journal of Money, Credit and Banking 41 (4), 673-709.

Petersen, M.A., Rajan, R.G., 1995. The effect of credit market competition on lending relationships. The Quarterly Journal of Economics 110 (2), 407-443.

Shaffer, S., 1997. The winner's curse in banking. Federal Reserve Bank Of Philadelphia Working Paper 97-25.

Shorrocks, A.F., 1978. The measurement of mobility. Econometrica 46 (5), 1013-1024.

Stein, J.C., 2002. Information production and capital allocation: Decentralized versus hierarchical firms. Journal of Finance 57, 1891-1921.

Tarashev, N.A., 2009. Measuring portfolio credit risk correctly: Why parameter uncertainty matters. BIS Working Papers 280. 